\title{
A STUDY ON OLIVER TWIST'S SADNESS IN CHARLES DICKENS' NOVEL
}

\author{
Eka Weny Widyaningsieh \\ Universitas Panca Sakti; Bekasi; Indonesia \\ Email; weny.widya12@gmail.com
}

DOI: $10.53754 /$ edusia.v1i1.122

\begin{tabular}{l|l|l}
\hline Received: 13 August 2021 & Revised: 27 September 2021 & Approved: 11 October 2021
\end{tabular}

\begin{abstract}
This research uses the innovative Oliver Twist novel. The purpose of this study is to describe the sadness that can be taken as a lesson from the main character in the Oliver Twist novel, and to show how the sadness is presented by the main character. This research deals with how sadness affects learning and can be found in a novel by Charles Dickens. In this scientific study and research, the writer uses descriptive qualitative to describe, analyze, and discuss research problems. Other information relevant to the investigation is also being sought by the researchers. The author conducted a research question to find how sadness can be reduced by studying "Oliver Twist" in a story from a functionalist perspective, symbol perspective, conflict, and perspective. After analyzing Oliver Twist novel the author found some sadness that can make life lessons in the main character, such as fortitude, sympathy, courage, honesty, cooperation, gratitude, not giving up easily, humility, and kindness.
\end{abstract}

Keywords: Charles dickens; novel; oliver twist; sadness; workhouse

Abstrak: Penelitian ini menggunakan novel Innovative Oliver Twist. Tujuan dari penelitian ini adalah mendeskripsikan kesedihan yang dapat diambil sebagai pelajaran dari karakter utama dalam novel Oliver Twist, serta menunjukkan bagaimana kesedihan yang disajikan karakter utama. Penelitian ini berkaitan dengan bagaimana kesedihan mempengaruhi pembelajaran dan dapat ditemukan dalam sebuah novel karya Charles Dickens. Dalam kajian ilmiah dan penelitian ini, penulis menggunakan deskriptif kualitatif untuk mendeskripsikan, menganalisis, dan membahas masalah penelitian. Informasi lain yang relevan dengan penyelidikan juga sedang dicari oleh para peneliti. Penulis melakukan penelitian pertanyaan untuk menemukan bagaimana kesedihan dapat dikurangi dengan mempelajari "Oliver Twist" dalam sebuah cerita dari perspektif fungsionalis, simbol, dan konflik. Setelah menganalisis novel Oliver Twist penulis menemukan beberapa kesedihan yang dapat menjadikan pelajaran hidup pada karakter utama, seperti ketabahan, simpati, keberanian, kejujuran, kerjasama, rasa syukur, tidak mudah menyerah, kerendahan hati, dan kebaikan.

Kata Kunci: Charles dickens; novel; oliver twist; sadness; workhouse 


\section{A Study On Oliver Twist's Sadness In Charles Dickens' Novel}

\section{INTRODUCTION}

Human is the original idealize creation of God. A Human beings cannot live by themselves, they will doubtlessly associate and communicate with the social community. Dialect is their media to communicate regularly. Language is the main media to communication each other. Besides, humans moreover can do a scholarly work by utilizing the dialect. It can be talk or composed frame which is as a rule called writing. The Novel, brief story, sonnet, dramatization and melody are a few illustrations of scholarly works.

According to Klarer, in his book entitled An Introduction to Literary Studies, literature is referred as a wholeness of the written expression, but in the exact sense of word not every written document can be categorized as a literature. Etymologically, the Latin word "litteratura" is derived from "littera" (letter). There are three major literary genres. ${ }^{1}$

It is like what Klarer states that because the epic was widely replace by the new prose form of the novel in the eighteenth century, recent classifications prefer the terms fiction, poetry, and drama as designations of the three major literary genres. Based on this opinion we know that literature is 'imaginative' writing in the sense of fiction. One of them is fiction. Fiction is a sort of literary works which the content is producing by human imagination. Some kinds of works that are categorized into fiction genres are novels, fables, novella, short stories, etc.

Sadness may be a state of moo disposition. Discouraged individuals may feel pitiful, on edge, purge, sad, powerless, useless, blameworthy, bad tempered or anxious. They have no curiously sense, uninterested in doing exercises that once were pleasurable, involvement misfortune of craving, or issues concentrating, recalling points of interest or making a choice and may mull over or endeavor suicide. ${ }^{2}$ A sleeping disorder, intemperate resting, weariness, misfortune of vitality, torments or stomach related issues that are safe to treatment may be slow.

The essayists are especially curious about Oliver Twist, as its book is incredibly notable that time. Other than Oliver Twist has been the subject of most film and television transformations, that fundamental for a significantly productive melodic play. The diverse Foundation Grant winning 1968 movie Oliver Twist! Oliver Twist is the second novel by home creator Charles Dickens, distributed by

\footnotetext{
${ }^{1}$ Klarer Mario, “An Introduction to Literary Studies Second Edition” (London:Routledge, 2004).

2 Wikipedia the free encyclopedia, “Sadness," accesed Agustus 16, 2021. https://en.wikipedia.org/wiki/Sadness
} 


\section{A Study On Oliver Twist's Sadness In Charles Dickens' Novel}

Richard Bentley in 1838. It is book uncover the Merciless Treatment of numerous a whithered stray - youngster in London, which Expanded global worry in what is in some cases known as 'The Incomparable London Whithered stray Emergency": various vagrants in London in the Dickens time. ${ }^{3}$

Here in Oliver Twist, sadness feeling shows up from starting until the conclusion of its story subsequently, the author is curious about making think about of sadness feeling.

Oliver's misfortune continued into adolescence, as he was forcing to become part of a gang of thieves in London, was abused by several people, and forced into a house burglary that left him poorly shot. But Oliver has been on good luck since he met the family.

Research that applies a qualitative descriptive model has been carried out by several researchers, but focuses more on the moral value of the learning model. Based on the literature study, the relevant research was conducted by Anisa Alawiyyah, Sri Hastin Oktavi in her journal entitled "The Analysis of Moral Values in Dangerous Minds Movie by John N. Smith" which analyzed descriptive learning of moral values in a film. ${ }^{4}$

The second research from the article journal of Rafy Fitriani, Rivi Antoni, Pipit Rahayu with the title "The Moral Values in Charles Dickens's Novel Oliver Twist" which analyzes moral values with a qualitative descriptive model, compared with the models that have been taught before and after, whether there are moral and values in the novel. ${ }^{5}$

The third study from the journal Lenny Solo entitled "Educational Values of The Main Characters in "The Importance of Being Earnest" Drama by Oscar Wilde" which analyzes the values of education in the application of a qualitative descriptive model. In this study, of course, only comparing with learning educational values in drama, is there anyone who can educate students by watching the drama. ${ }^{6}$

${ }^{3}$ Theauzty, "A Study of Oliver Twist' Depression Found in Oliver Twist by Charles Dickens," Accesed Agustus 16, 2021, https:/ / theauzty.wordpress.com/

4 Anisa Alawiyyah, Sri Hastin Oktavi, "The Analysis of Moral Values In Dangerous Minds Movie By John N. Smith." Dialectical Literature and Educational Journal, vol 4 no. 1, 2019, https://doi.org/10.51714/dlejpancasakti.v4i1.6.pp.18-26

5 Rafy Fitriani, Rivi Antoni, Pipit Rahayu, "An Analysis of Moral Values in Novel "Oliver Twist" by Charles Dickens." Jurnal Mahasiswa Prodi Bahasa Inggris UPP, vol. 2, no. 1, 2016, https://www.neliti.com/publications/109486

${ }^{6}$ Lenny Solo,"Educational Values of The Main Characters in "The Importance of Being Earnest" Drama by Oscar Wilde." Dialectical Literature and Educational Journal, vol 5 no. $1, \quad 2020$, https://doi.org/10.51714/dlejpancasakti.v5i1.19.pp.33-42 


\section{A Study On Oliver Twist's Sadness In Charles Dickens' Novel}

The next research is the journal from Laili Rasikhatun Nida Awalin, Jafar Shodiq entitled "Analysis of Translation Techniques and Quality of Translation of the Serial Film "The Boss Baby" on Netflix" which analyzes translation techniques and translation quality in applying qualitative descriptive models. In this study, it can be compared from learning serial films from Netflix, whether there are good translation techniques and quality so that students can take them by watching the series. $^{7}$

Subsequent research from the journal Ting LONG, Xue JIANG entitled "Analysis on the Reality of Oliver Twist from the Perspective of Sociohistorical Criticism" which analyzes the reality of sociohistorical criticism in the application of this qualitative descriptive model where students must learn about the reality of the main character. In this study, is there sociohistorical criticism that can be used as student learning after reading the novel. ${ }^{8}$

It should be realized that research on learning with novels is numerous and varied. However, if it is explored more deeply related to research on how to teach learning from a sadness from a novel, it is still lacking. Therefore, this article will provide an idea or picture that can be done by the teacher in an effort to learn from the sadness that the main character of the Oliver Twist novel goes through.

In this research, researchers chose Oliver Twist by Charles Dickens as the object of research and study researcher novel story. Therefore, the researcher conducting the research entitled "A Study on Oliver Twist's Sadness in Charles Dickens' Novel.

\footnotetext{
${ }^{7}$ Laili Rasikhatun Nida Awalin, Jafar Shodiq,"Analysis of Translation Techniques and Quality of Translation of the Serial Film "The Boss Baby" on Netflix." Linguistics and Education Journal, vol 1 no 1, 2021, http://journal.upgris.ac.id/index.php/lic-ed/article/view/9403

8 Ting Long, Xue Jiang, "Analysis on the Reality of Oliver Twist from the Perspective of Sociohistorical Criticism," Cross-Cultural Communication, Vol 17 no 2, 2021, http://dx.doi.org/10.3968/12159
} 


\section{A Study On Oliver Twist's Sadness In Charles Dickens' Novel}

\section{METHOD}

This research uses technical qualitative research. It was part of a qualitative method research design that allowed researchers to describe a phenomenon by presenting many facts without trying to interpret them. Moloeng says: Qualitative research is research that aims to understand the phenomenon of what is experienced by the subject of the study such behavior, perception, motivation, action, and so on, in a holistic manner and by way of description in the form of words and language, in a specific context that is natural and with utilizing a variety of natural method. ${ }^{9}$ It means that the qualitative research focused on the understanding in the concept of the research and human experience.

According to Arikunto, the source of the data refer to the subject form which the data was obtained. Therefore, research is a literary study, and was considered the material of study. ${ }^{10}$ When collecting data, researchers acquired two kinds of data. They were primary data and supporting data.

Researchers in this study used data collection techniques such as the data collection stage to collect data such as: The researcher reads Oliver Twist's novel and learns all the sentences in the novel, researchers read references to previous research results, researchers watch the Oliver Twist movie, researchers predict/analyze data, searchers draw conclusions based on data analysis.

The research was held on Maret 2021. The researcher has conducted the research by sadness of the novel "Oliver Twist." The Researcher then describes A Study on Oliver Twist's Sadness in Charles Dicken's Novel.

Research needs process of procuring primary data. In qualitative research, the main data sources are words and action. The rest are additions such as, documents, articles, internet and others.

The researcher makes the data reduction by making summary, choosing the main point things, focusing on important things, find out themes and pattern. Thus, it will make the researcher easier to conduct further data collection, because the data that has been reduced will provide clearer understanding.

\footnotetext{
${ }_{9}^{9}$ Moleong Lexy, Metode Penelitian Kualitatif (Bandung: RemajaRosdakarya, 2007)

${ }^{10}$ Suharsimi Arikunto, Prosedur Penelitian: Suatu Pendekatan Praktik (Jakarta: Rineka Cipta, 2011)
} 


\section{A Study On Oliver Twist's Sadness In Charles Dickens' Novel}

Data Presentation : A set of the main point information that is useful to help the researcher to understand a certain part of the research. The presentation of data can be displayed in the form of a brief description or table.

The last step in the data analysis process, in this section, after the researcher observers Beauty and the Beast Movie to find out the moral value from this movie, then the researcher summarizes the data that has been obtained.

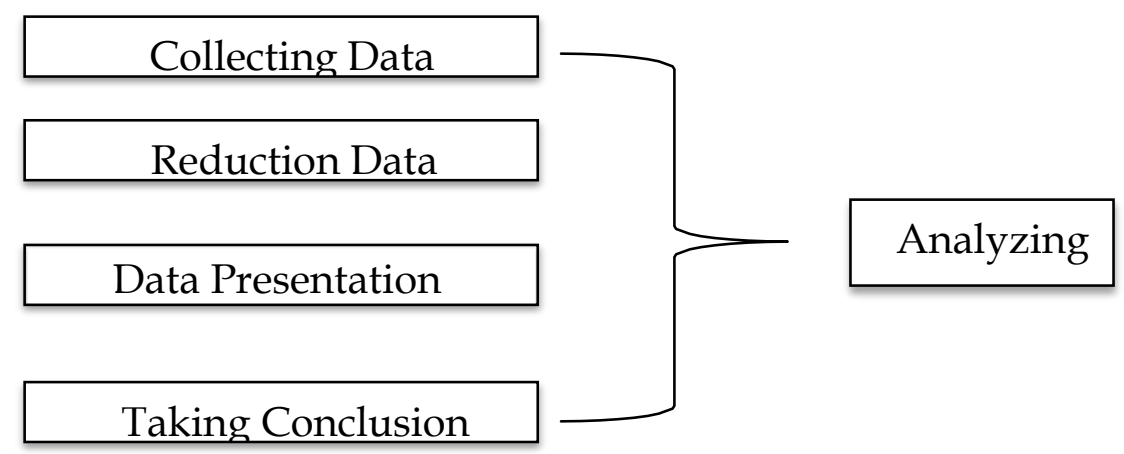

The research approach used in this research is qualitative with the type of literature study. This research was conducted by looking for theoretical references that are relevant to the problems found. The data is obtained from articles, books, and other documents that can describe the theory and information needed.

The steps of data analysis of novel: (1) Gather references related to the analysis of the novel; (2) Describing synopsis of the novel and biography of the author; (3) About grief nested in a novel about psychological theory; and (4) Finish the data analysis to answer the sentence in question.

\section{REVIEW OF THE RELATED LITERATURE}

Literary Appreciation, Character, Conflict, and Sadness make up this chapter. The explanation can be seen below:

Literature is all of the most commonly written works. More restrictively, literature refers to articles that are considered artistic forms or single sentences that are considered art or intellectually valuable, and often develop the language in a way that is different from its general usage. Because it is Latin root literatura / literature (derived itself from literra: letter or handwriting) was used to refer to all written records. This concept has changed its meaning over time to include text (oral literature) and non-literal linguistic artistic forms that speak or sing.

According to scientists, literature has several meanings. All literature is referred to as the whole written expression with the limitation that the document is not classified into literature with a more accurate meaning. 


\section{A Study On Oliver Twist's Sadness In Charles Dickens' Novel}

Therefore, the definition generally includes the additional adjective aesthetics\| or -artisticll In the same book, literally an introduction to research. Klarer also said that the production of literature lasts longer than the creator, as human desires do exist in isolation from the individual, leaving their mark through creative expression. ${ }^{11}$

By reading literature we can get the message and understand the characters that are in the literature. Based on the above theory, the author concludes that literary appreciation is based on the understanding that literature is useful in literature. There are values to life and have a feeling of sensitivity to life's problems. The social theme of poverty is raised in various events. Oliver's twist is popular because Charles Dickens lived in a poor society and an unhappy childhood life has a strong character in the novel.

The author established the various constituent elements, literature does not automatically emerged in the process creation. Dickens combines old stories with the latest or modern stories, making the latest industrial revolution, that the whole story can change. If we want the best example of this novel is Oliver Twist. Really to some other Dickens work. Oliver Twist is not something big but something very important, from his life that is so rude and so melodrama.

Character, all stories need certain necessary elements. Without these elements, literary works often fail to make sense. For instance, one of the essential elements of every story is a plot with a series of events. Another important element is a character. A character can be any person, a figure, an inanimate object, or animal. There are different types of characters, and each serves its unique function in a story or a piece of literature. There are four types of characters: 12

Antagonist: The antagonist is the villain, or the opponent of the protagonist or main character. Between the protagonist and the antagonist this can lead to conflict or action that makes the story more alive. Antagonists can be people, animals, or nature itself.

\footnotetext{
11 Klarer Mario, “An Introduction to Literary Studies Second Edition” (London:Routledge, 2004).

12 Literary Devices, "Definition of Character," accesed Agustus 16, 2021. https://literarydevices.net/character
} 


\section{A Study On Oliver Twist's Sadness In Charles Dickens' Novel}

Protagonist: Each story has a main character, who creates plot action and engages the reader, awakening their empathy and interest. The protagonist is the main character or hero in the story, because the whole plot moves around him and the story is entirely about him.

Round Character: The round characters are well-developed and complex figures in a story. They are more realistic, and demonstrate more depth in their personalities. They can make surprising or puzzling decisions, and attract readers' attention. There are many factors that may affect them, and round characters react to such factors realistically.

Flat Character: A flat character does not change during a story. Also, he or she usually only reveals one or two personality traits.

The function of this theory is to characterize Oliver Twist's sadness. By using this theory, it is easy to find the sorrow of the writer Oliver Twist. The character supports the discussion.

Conflict can be defined in many ways and can be considered as an expression of hostility, negative attitudes, antagonism, aggression, rivalry and misunderstanding. ${ }^{13}$ It is also associated with situations that involve contradictory or irreconcilable interests between two opposing groups. A few definitions of conflict are as given below: "A simple definition of conflict is that it is any tension which is experienced when one person perceives that one's needs or desires are likely to be thwarted or frustrated".

The conflict that prioritizes reality. This Oliver Twist novel, if traced, might be categorized as a novel that provides a lot of criticism of the era in which the author lives and lives. Oliver Twist is one of the novels that tells the reality of British life during the reign of Queen Victoria which is estimated around the 18th century when the industrial revolution occurred on a large scale. Actually in this novel the story that is mostly told is about the life struggle of a child who is an orphan.

Sadness is often the result of other emotions such as anger, stress, guilt, sadness, anxiety and despair. Sometimes other emotions are so strong that you don't even know you're sad.

What is sad? You can change the way you feel physically. Perhaps you have a stomachache, headache or cannot sleep.

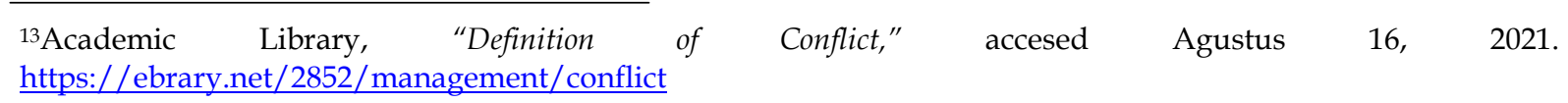




\section{A Study On Oliver Twist's Sadness In Charles Dickens' Novel}

Sadness may also change the way you feel emotionally. Perhaps you are teary-eyed, sullen, bored, frustrated, or just want to avoid others.

The effects from Sadness

Life is full of situations that can make people sad: (1) Having problems at home (family fights and domestic violence); (2) Having problems at school or work or there; (3) Feeling pressure; (4) Going home and losing a loved one or friend; (5) Caring for someone who is ill or sick; (6) Experiencing chemical changes in the body (puberty, medicine, drugs, etc.); (7) Experiencing a change of thinking (For example, to develop a useless thinking style) to be self-critical or to learn new information on topics such as poverty and terrorism). ${ }^{14}$

When faced with such a situation, you may have your sadness, worthless, or negative thoughts. And that thought has the potential to make you feel bad.

Try the other way: Acknowledge your grief and the circumstances that urge it. And you are giving yourself time to solve any problems and feel better. You can also contact resources that can be helpful (for example, friends and family, psychologists and other healthcare professionals). ${ }^{15}$

Supporting someone else who is feeling sad, perhaps you know someone else who feels sad. It is hard to understand why someone is unhappy and how they are coping, so it is not always easy to apply.

Here are four essential tips: (1) Ask the person if they like it. I am interested when I check it; (2) Listen without judging; (3) If the person cares about asking someone for help (such as a school counselor, work HR representative, or doctor), suggest contact information to call with them. You can give it helpful to find; (4) Rest assured that sadness is a valid emotion and can be overcome.

\section{DISCUSSION}

In this chapter, the sign of sadness experienced by the protagonist is to discuss the causes and effects. Many sadness has causes and consequences. Our group describes each piece of evidence that the symptoms of sadness experienced at Charles Dickens' Oliver Twist cause and effect.

14 Wikipedia the free encyclopedia, "Sadness," accesed Agustus 16, 2021. https://en.wikipedia.org/wiki/Sadness 15 Wikipedia the free encyclopedia, "Sadness," accesed Agustus 16, 2021. https://en.wikipedia.org/wiki/Sadness 


\section{A Study On Oliver Twist's Sadness In Charles Dickens' Novel}

\subsection{The Symptoms and The Causes of Sadness Undergone in Oliver Twist Evidence 1}

'Bow to the board,' said Bumble. Oliver brushed away two or three tears that were lingering in his eyes, and seeing no board but the table, fortunately bowed to that. ${ }^{16}$

"What your name, boy?" said the gentleman in the high chair.

Oliver was frightened at the sight of so many gentlemen, which made him tremble and the beadle gave him another tap behind, which made him cry. These two causes made him answer in a very low and hesitating voice, whereupon a gentleman in a white waistcoat said he was a fool. Which was a capital way of raising his spirit, and putting him quite at his ease. ${ }^{17}$

It very well may be demonstrated that Oliver Twist goes through loss of revenue. Albeit the board never meet him. They rapidly choose him as a bonehead kid. That circumstance makes him feel off kilter with everything around him (the climate, individuals, and the exercises).

It very well may be demonstrated that Oliver Twist goes through social disengagement. The new situation made him awkward especially after he chose as an unsafe child at his new workhouse at their first meeting. He startles with nearly everyone there. In this way, he apprehensive and can't answer his name plainly when they ask him.

\section{Evidence 2}

“Tol de rol lol lol, right fool lairly, work us,' said Noah, as a tear rolled down Oliver's cheek. 'What is set you a snivelling now?".

“Not you,' replied Oliver, sharply. "There, that's enough. Don't say anything more to me about her, you'd better not!"

“Better not!' exclaimed Noah “Well! Better not work us, don't be impudent. Your mother, too! She was a nice "un she was. Oh lor!" and here, Noah nodded his head expressively, and curled up as much of his small red nose as muscular action could collect together for the occasion. ${ }^{18}$

\footnotetext{
${ }^{16}$ Charles Dickens, Oliver Twist (Jakarta: Gramedia Pustaka Utama, 2017)

${ }^{17}$ Charles Dickens, Oliver Twist (Jakarta: Gramedia Pustaka Utama, 2017)

${ }_{18}$ Charles Dickens, Oliver Twist (Jakarta: Gramedia Pustaka Utama, 2017)
} 


\section{A Study On Oliver Twist's Sadness In Charles Dickens' Novel}

This may indicate a problem with the Oliver Twist concentration. Oliver upset Mrs. Sowerbury and Mr. Bumble because Oliver beat Noah (Oliver is angry with Noah. Noah always jokes Oliver by making fun of his mother). Mrs. Sowerbury tries to stop it, but she can't because Oliver has deep anger. When everyone is tired, the situation stops.

May indicate that Oliver Twist is suffering from childhood trauma and abuse. After Oliver sees the cellar, Oliver receives a bit not only from Mr. Sowerbury, but also from Mrs. Sowerbury and Mr. Bumble. Then I spent the rest of the day in the back room. The bottom line is that Oliver's life wasn't handled properly by his boss.

\section{Evidence 3}

Mr. Sikes, dragging Oliver after him, elbowed his way through the ticket of the crowd and bestowed very little attention on the numerous sights and sounds, which so astonished the boy. He nodded, twice or thrice, to a passing friend, and resisting as many invitations to take a morning dram, pressed steadily onward, until they were clear of the turmoil, and had made their way through Hosier Lane into Holborn.

"Now, young 'un!" said Sikes, looking up at the clock of St. Andrews Church, "hard upon seven! you must step out. Come, don't lag behind already, lazy leg!"

Mr. Sikes accompanied this speech with a jerk at his little companion's wrist, Oliver, quickening his pace into a kind of trot between a fast walk and a run, kept up with the rapid strides of the housebreaker as well as he could. ${ }^{19}$

Oliver Twist reveals that he is experiencing feelings of helplessness and hopelessness. Oliver appeals to Sikes for freedom. In his heart he does not want anything of it, but he is anything against the heart. Especially holding a gun in his heat.

May indicate that Oliver Twist is suffering from childhood trauma and abuse. He's too young when it all happened to him. He has a lot of pressure and suicide from his boss (the original owner of the workhouse), from everyone around the bookstore, from the police, from the thieves, and the most challenging part is in Sicus, who is always afraid to put a gun to his head.

${ }^{19}$ Charles Dickens, Oliver Twist (Jakarta: Gramedia Pustaka Utama, 2017) 


\section{A Study On Oliver Twist's Sadness In Charles Dickens' Novel}

\subsection{The Effects of Sadness Undergone in Oliver Twist}

\section{Evidence 1}

"Poor boy, poor boy!" Said Mr. Brownlow, clearing his throat. "I am rather hoarse this morning, Mrs. Bedwin. I am afraid I have caught cold."

"I hope not sir," said Mrs. Bedwin. "Everything you have had, has been well aired, sir." 20

Oliver Twist reveals that he is experiencing feelings of helplessness and hopelessness. He feels helpless because he knows that no one will help him if he complains again. And he feels pain because he also feels despair all his life at the moment of his disappointment. He finds it the best he can get there. He is grateful for it over death.

\section{Evidence 2}

They held their course at this rate, until they had passed Hyde Park corner, and were on their way to Kensington: when Sikes relaxed his pace, until and empty cart which was at some little distance behind came up. Seeing 'Hounslow' written on it, he asked the driver with as much civility as he could assume, if he would give them a lift as far as Isleworth.

"Jump up," said the man. "Is that your boy?"

"Yes, he is my boy," replied Sikes, looking hard at Oliver, and putting his has abstractedly into the pocket where the pistol was. ${ }^{21}$

It could mean that Oliver Twist is being bullied. He stopped the escape of those who accused Oliver of being a thief because he won the mouth. The gentleman pushes him out before pulling him to identify Oliver.

\section{Evidence 3}

"What's that!" he cried, starting up and catching sight of a figure standing by the door. "Who's there?".

"Me. Only me," replied a tremulous voice.

Oliver raised the candle above his head: and looked towards the door. It was Nancy. ${ }^{22}$

\footnotetext{
${ }^{20}$ Charles Dickens, Oliver Twist (Jakarta: Gramedia Pustaka Utama, 2017)

${ }^{21}$ Charles Dickens, Oliver Twist (Jakarta: Gramedia Pustaka Utama, 2017)

${ }^{22}$ Charles Dickens, Oliver Twist (Jakarta: Gramedia Pustaka Utama, 2017)
} 


\section{A Study On Oliver Twist's Sadness In Charles Dickens' Novel}

"Put down the light," said the girl, turning away her head. "It hurts my eyes." Oliver saw that she was very pale, and gently inquired if she were ill. The girl threw herself into a chair, with her back towards him and wrung her hands, but made no reply. ${ }^{23}$

Oliver Twist reveals that he is experiencing feelings of helplessness and hopelessness. Of all that he tried to escape because he could not do anything and he was killed by Feigin and his friends. He just does what they say.

\section{CONCLUSION}

The writer analyzes the evidence and, based on the findings, concludes that post-sadness is a bad mood. Sadness can be seven symptoms: a feeling of helplessness and hopelessness, loss of interest in daily activities, changes in appetite or weight, irritability or restless self-loathing, unexplained aches and pains, and difficulty concentrating. The main symptoms are feelings of helplessness and hopelessness.

His life nobody has shelter. He had no parents, and he last knew no family. He only knew that Mr. Brownlow was his grandfather. The deep hopelessness that accompanies sadness can lead to suicidal thoughts as the only way out of suffering. In this case, we focus on Oliver Twist as our protagonist who is always trying to get his hands on his freedom. It also helps the author analyze the causes and effects of Oliver Twist's sadness. Experience with Oliver Twist, loneliness, social isolation, stressful life events, trauma or abuse of a child as a cause. The leading reason is stressful life events. He experiences a lot and puts him under more profound stress.

Finally, the result of Oliver Twist is escape, self-harm, violence, suicide, helplessness and hopelessness. The dominant product are violence, helplessness and hopelessness. All of its result has positive and negative aspects to Oliver. But most of the impact is harm.

\footnotetext{
${ }^{23}$ Charles Dickens, Oliver Twist (Jakarta: Gramedia Pustaka Utama), 2017
} 


\section{REFERENCES}

A. J. Cuddon, A Dictionary of Literary terms and Literary Theory (UK: Wiley-Blackwell, 2013)

Academic Library, "Definition of Conflict," accesed Agustus 16, 2021. https://ebrary.net/2852/management/conflict

Alfi Nurbaeti, "An Analysis of Educational Values in Novel "The Alchemist" By Paulo Coelho" (Universitas Panca Sakti Bekasi, 2018)

Anisa Alawiyyah, Sri Hastin Oktavi, "The Analysis of Moral Values In Dangerous Minds Movie By John N. Smith." Dialectical Literature and Educational Journal, vol 4 no. 1, 2019, https://doi.org/10.51714/dlejpancasakti.v4i1.6.pp.18-26

Arifuddin, An Analysis of Social Conflict in Rick Riordan's Novel "The Red Pyramid" (UIN Alauddin Makassar, 2014)

Charles Dickens, Oliver Twist (Jakarta: Gramedia Pustaka Utama, 2017)

Laili Rasikhatun Nida Awalin, Jafar Shodiq,"Analysis of Translation Techniques and

Quality of Translation of the Serial Film "The Boss Baby" on Netflix." Linguistics and Education Journal, vol 1 no 1, 2021, http://journal.upgris.ac.id/index.php/lic-ed/article/view/9403

Lenny Solo,"Educational Values of The Main Characters in "The Importance of Being Earnest" Drama by Oscar Wilde." Dialectical Literature and Educational Journal, vol 5 no. 1, 2020, https://doi.org/10.51714/dlejpancasakti.v5i1.19.pp.33-42

Lexy J. Moleong, Metodologi Penelitian Kualitatif (Bandung: Remaja Rosdakarya, 2018) Literary Devices, "Definition of Character," accesed Agustus 16, 2021. https://literarydevices.net/character

Muntamah, "An Analysis of Moral Values as Seen On Charles Dickens' Novel Oliver Twist" (IAIN Salatiga, 2020). http://erepository.perpus.iainsalatiga.ac.id/id/eprint/7365

Nina Siti Maryam, "An Analysis of Moral Value as Seen in Female Lead Character in Beauty and the Beast Live Action Movie" (Universitas Panca Sakti Bekasi, 2020).

Rafy Fitriani, Rivi Antoni, Pipit Rahayu, "An Analysis of Moral Values in Novel "Oliver Twist" by Charles Dickens." Jurnal Mahasiswa Prodi Bahasa Inggris UPP, vol 2, no. 1, 2016, https://www.neliti.com/publications/109486

Rafy Fitriani, Rivi Antoni, Pipit Rahayu, “An Analysis of Moral Values in Novel Oliver Twist Charles Dickens" (University of Pasir Pangaraian, 2015)

Suharsimi Arikunto, Prosedur Penelitian: Suatu Pendekatan Praktik (Jakarta: Rineka Cipta, 2011)

Theauzty, "A Study of Oliver Twist' Depression Found in Oliver Twist by Charles Dickens," Accesed Agustus 16, 2021, https://theauzty.wordpress.com/ 


\section{A Study On Oliver Twist's Sadness In Charles Dickens' Novel}

Ting Long, Xue Jiang, "Analysis on the Reality of Oliver Twist from the Perspective of Sociohistorical Criticism," Cross-Cultural Communication, Vol 17 no 2, 2021, http://dx.doi.org/10.3968/12159

Wikipedia the free encyclopedia, "Sadness," accesed Agustus 16, 2021. https://en.wikipedia.org/wiki/Sadness

(C) 2021 by the Authors. Submitted for possible open access publication under the terms and conditions of the Creative Commons Attribution-NonCommercial 4.0 International License (CC BY NC) license (https:// creativecommons.org/licenses/by-nc/4.0/). 